\title{
The New ILO in Sub-Sabaran Africa: Action, Agency, and Ordering Under Global Production
}

\author{
Nick Bernards, McMaster University, Hamilton, Canada
}

\begin{abstract}
This article examines recent changes in the role played by the International Labour Organization in Sub-Saharan Africa in historical perspective. It argues that the globalization of production has created a novel set of political and economic problems surrounding work and labour in Africa. The ILO's activities in Africa have been an important means by which African states and organized labour, along with the ILO itself, have adapted themselves to these challenges. These programmes have opened up new opportunities for action by states and workers in Africa, but these have at times been used in exclusionary ways. This argument is advanced by first considering the historical trajectory of the ILO's activities in Africa and then by examining two new programmes, the Decent Work Country Programmes initiative and Better Work Lesotho, in more detail.
\end{abstract}

\section{KEYWORDS}

Africa, global governance, globalization of production, International Labour Organization, international political economy

\section{Introduction}

From the late 1990s, the role of the International Labour Organization (ILO) in the global political economy has shifted dramatically. The transformation of the ILO's relationship with Sub-Saharan Africa has been one of the most striking changes. The region seemingly went overnight from an afterthought to the centerpiece of many new programmes and initiatives. In the past decade the ILO has taken on an active role in shaping policy through its Decent Work Country Programs (DWCPs), helped reinforce private voluntary labour regulations in Lesotho through its Better Work initiative, played a significant role in debates over pensions, increased its involvement in technical and financial aid allocation, and even helped to establish cooperatives in Eastern and Southern Africa. Two obvious questions suggest themselves. The first is explanatory: why Africa and why now? The second is evaluative: how well can these new 
programs improve developmental and distributional outcomes for Africans and African workers?

These questions are both best answered by considering the historical relationship between the ILO and Africa in its global context. Robert Cox and others have made note of the precarious relationship between the ILO and the structure of prevailing world orders (e.g. Cox 1977, 1980; Vosko 2002). For much of its history the institution has walked a fine line between incorporating some segments of labour into structures of hegemonic order and providing opportunities for workers to better their position within those structures. Building on these previous analyses, this paper argues that the ILO's activities in Africa represent an effort at managing the political challenges arising out of the globalisation of production for states, civil society, and international organizations. Where in previous periods the ILO's priorities and those of African states and labour were broadly incompatible, the globalisation of production poses complementary challenges to both. This has pushed African states and organised labour into closer coordination with the ILO. These new modes of cooperation have facilitated the efforts of some actors in dealing with the challenges posed by global production, while simultaneously reinforcing some patterns of exclusion and domination.

The ILO's activities, then, are best understood in relation to the interactions between prevailing structures of production and political order at national and international levels. This approach stands to make a valuable contribution to understanding this topic for two reasons. First, it offers a broader and more complete picture of the recent changes (1) in the role of the ILO in world politics, and (2) in African labour relations than can be offered by approaches focused on one or the other. Authors have often applied perspectives on the bureaucratic politics of IOs (see Barnett and Finnemore 2004) or international law in attempts to explain the ILO's recent activities (e.g. Cooney 1999, Helfer 2006). Most studies of African labour relations, on the other hand, tend to focus on the national or comparative level (see e.g. Wood and Brewster 2007) rather than the global or international context.

Second, it offers a means of moving beyond simply questioning the effectiveness or desirability of particular policies in order to ask questions about what this case can say about the possibilities and limitations of the existing structures of the global political economy. The evaluative question introduced above has preoccupied a good deal of recent commentary on the ILO. Standing $(2008,2010)$ has criticized the ILO for moving towards a focus on a limited set of 'negative' rights - for instance the abolition of child labour or prohibitions of discrimination - at the expense of 'positive' enabling social rights. Caraway (2006) has similarly criticized the ILO for advocating a model of 'free association' encouraging competition among fragmentary unions rather than powerful centralized collective bargaining. A number of other authors conversely suggest that this shift represents an appropriate prioritization of its activities and adaptation to changing circumstances (Rodgers et al. 2009, Blanpain and Engels 2001, Hughes 2005, Helfer 2006, Cooney 1999).

By looking at the ILO's programs in Africa in their wider historical and global context, the approach taken here enables serious consideration not only of the desirability of the ILO's policies in Africa but also of the possibilities and limitations within which they operate. The 
fundamental power relationships and political accommodations through which these programs are formulated and implemented have significant implications for their potential effectiveness.

\section{THE ILO, AFRICA, AND WORLD ORDER - THREE PERIODS}

I advance this argument by presenting a historical narrative outlining the role of the ILO in Africa through three configurations of social relations of production and world order:

1. From the end of World War II until around 1980 the ILO acted as a proponent of the tripartite model of social relations of production that dominated Europe and North America. Tripartism applied poorly to the African context and African states were preoccupied with development and the consolidation of state power in their foreign affairs. The ILO's activities in Africa were thus quite limited.

2. Between the early 1980s and the late 1990s, the emergence of global forms of production led to a breakdown of both tripartism and the post-independence African state. The ILO struggled for most of the period to make itself relevant to the changing global order. Production in Africa was substantially reshaped in this period, posing significant political challenges for organized labour and states across the continent.

3. In the last ten to fifteen years the ILO has adopted a new role and new priorities in order to adapt itself to contemporary social relations of production. The ILO's activities in Africa in this sense represent efforts to establish a new, albeit weak, form of political order regulating global production. The priorities adopted by the ILO and by African states and civil society in this period are much more compatible than in previous periods.

This third period is the primary focus of the paper. Emphasizing the historical development of the relationship between the ILO and Africa will underscore the importance of the reciprocal relationship emphasized in this paper. Thus, the paper considers each of these periods separately, examining the ways in which the interactions between the social relations of production and political order has played out through the relationship between the ILO and Africa.

\section{Tripartism, Embedded Liberalism and the Post-independence State}

Ruggie (1982) has described the world order that prevailed after World War II as 'embedded liberalism': a system of open economic exchange in which states could still intervene to protect domestic markets and social outcomes. Production in the core economies was generally organized on the basis of tripartite coordination between large industrial firms, national or sectoral trade union confederations, and the state. Tripartism was aimed at the bureaucratization of labour relations, the maintenance of high standards of living for unionized workers, and the stabilization of cyclical patterns of economic activity (Cox 1987: 74-82). However, this was hardly an egalitarian order. Standing (1999) and Harrod (1987) in 
particular have argued that economic security was the privilege of white, male, unionized workers in the developed world.

The ILO's activities in relation to this order were shaped by two factors. First, the conflicted relationship between the United States and the ILO often preoccupied the institution. American government, business and labour often sought either to dominate the organization or (failing that) to undermine it. The Cold War conflict thus deeply permeated the activities of the ILO. American organized labour, especially the dominant American Federation of Labour - Congress of Industrial Organizations, was as concerned with preventing the spread of communism as the United States government. Second, the ILO played a key role in legitimating the tripartite arrangement of social relations of production that prevailed in Europe and North America through its standard setting and research activities. The ILO's role was in these respects closely linked to the prevailing Americandominated embedded liberal world order and tripartite mode of social relations of production (see Cox 1977, Lorenz 2001, Myconos 2005).

\section{AFRICAN POLITICAL ECONOMY POST-INDEPENDENCE}

Africa's relationship with the ILO in this period was limited by precisely these two defining features. In the first instance, tripartism was a poor fit in Africa, although for different reasons in tropical Africa and in the white ruled states in southern Africa.

At the time of independence neither a well-developed capitalist class nor a strong working class was present in tropical Africa. Most of the population was engaged in small-scale agriculture. Neither were there many strong states. Further, organized labour, capital and the state as had developed in Africa at the time were often closely entwined. There is little need to recap in detail here the debates about the intertwinement of the so-called 'bureaucratic' and 'business' bourgeoisies and the centrality of the state apparatus to strategies of accumulation in Africa (see Bayart 2009: Ch. 3). For the purposes of this paper it will suffice to note the close integration of the state and bureaucracy with both foreign and indigenous capital typical of most African countries in the period in question.

Trade unions were generally also closely integrated into the single party state. This involved the differentiation between a unionized working class on the one hand and the great bulk of the population on the other - both the urban informal sector and rural agricultural labour, mostly smallholders. A certain degree of ambivalence on the part of unions about the loss of independence was visible - especially among rank and file workers (see Jeffries 1978, Lukes 1984). Nonetheless, organized labour was typically under the control of the state.

Contemporary authors (Berg 1966) and later commentators (Panford 1994) have noted that this close relationship between the state, capital and labour made it difficult for the state to participate in tripartite negotiations as an impartial referee, and indeed complicated bipartite negotiations between capital and labour. The ILO's preferred model of tripartism, in short, was a poor fit with the structures of production and political order that predominated in tropical Africa at the time. 
Tripartism was also a poor fit, albeit for different reasons, in the white-ruled states of southern Africa. ${ }^{1}$ Relative to tropical Africa there were well developed capitalist and working classes, but the racial structure of labour relations in South Africa and its satellites posed its own set of problems. While the ILO did engage with the white unions and the Apartheid regime in the immediate post-war period, it distanced itself from the white government as antiApartheid unions increasingly appealed to the ILO for legitimation. The ILO ultimately cut off relations with the Apartheid regime in 1964.

\section{AFRICA IN THE EMBEDDED LIBERAL WORLD ORDER}

A second major limitation on the role of the ILO, at least as far as 'tropical' Africa is concerned, was posed by the ILO's preoccupation with the Cold War conflict. This sat at odds with the primacy of developmental concerns in African governments' external relations.

Two issues occupied the bulk African foreign affairs in the early post-independence period. First, a good deal of time was expended on regional diplomacy within Africa aimed at consolidating borders in ways that would allow state building projects to be carried out without interference (Herbst 2000). Second, and more importantly for the purposes of this paper, most of the continent's leaders were more interested in the North-South conflict than in the Cold War conflict. Given limited capacity to transform domestic societies, the idea that development issues were primarily exogenous was politically convenient and intuitively appealing (Murphy 1983, Shaw 1979). The priority assigned to development and statebuilding meant that the United Nations Conference on Trade and Development and General Assembly rather than the ILO or other specialized agencies, were the focus of most African governments' engagements with the international system (Taylor 2003).

The ILO did play some, albeit limited and relatively passive, role in Africa in this period (see Panford 1994). Zambia, for instance, ratified 45 ILO conventions between 1977 and 1983 - including 35 in 1983 alone (Kalula 1985). African states faced few repercussions for not adhering to the Conventions they ratified. Adopting ILO standards could thus bring some international political benefit at very little cost or risk. Nonetheless, the opportunity was rarely taken.

\section{Globalizing Production, the State, and Unprotected Work}

The embedded liberal order and the post-independence state in Africa had collapsed almost completely by the end of the 1980s. The Apartheid system in southern Africa followed in the early 1990s. It will serve little use to dwell on the near-global shift to neoliberal economic governance here. Rather, I examine changes to the structure of African political economy, the impacts of the globalization of production, and the challenges faced by the ILO. 


\section{STRUCTURAL ADJUSTMENT AND LIBERALIZATION}

The state-led model of development in Africa and elsewhere had come to rest on high levels of external borrowing which were no longer possible after the early 1980s. Almost all states on the continent turned at some point to the Bretton Woods institutions for emergency loans, which were conditional on adopting structural adjustment packages (SAPs) aimed at radical economic liberalization. South Africa, in less dire financial straits but facing the difficult economic transition away from Apartheid, underwent a similar process of liberalization in the 1990s. Two things about SAPs are significant here. First, economic opening was a necessary condition for Africa's involvement in global production. Second, and more importantly, labour was ejected from ruling coalitions (Tidjani 1998). Structural adjustment broke the formerly close links between organized labour and the state, as well as weakening unions' bargaining power with employers.

Structural adjustment also indirectly undermined many of the single party or military governments that had predominated after independence. Unions and social movements negatively impacted by SAPs played a major role in the nearly region-wide advent of multiparty elections. Democratization, however, did little to alter economic policies or outcomes. Trade unions have thus remained largely oppositional in their relations to the state since (Kraus 2007). This distance created a novel set of challenges for both. For unions, access to financial and organizational resources is limited. For states, the loss of control over trade unions has created a need to find new means of managing politically dangerous labour issues.

\section{THE GLOBALIZATION OF PRODUCTION}

The other major change in this period was the globalization of production. Social relations of production are increasingly organized on a global scale. The major driving force behind the global reorganization of production has been the growing structural power of major transnational corporations. Structural power is understood, following Susan Strange, as power over the way activity is organized and the availability of resources (Strange 1988, 1996; cf. Gill and Law 1989). The most obvious way in which this is evident is the expansion of foreign direct investment (FDI). FDI flows expanded dramatically after 1980 - growing from less than one hundred billion USD to a peak in 2007 at over two trillion USD (UNCTAD 2010: 2, fig. 1.1). Granted, by this measure Africa is not particularly 'globalised', receiving a negligible proportion of total world FDI (UNCTAD, n.d.).

However, a second important set of developments - transnational outsourcing, subcontracting and other flexible production strategies - is increasingly important. The global value chains or global production networks literature is tremendously useful in pointing to these developments (see Gereffi and Korzeniewicz 1994, Henderson et al. 2002). Gereffi's (1994) concept of a 'buyer driven' value chain is particularly useful here. Retailers with recognised brands dominate access to lucrative markets in the developed world. This enables them to set standards for suppliers governing the quality and cost of finished goods, as well as the timing, cost and qualitative aspects of the processes by which they are produced (Gereffi, Humphrey and Sturgeon 2005, Kaplinsky 2010). To put the concept into the terms used here, 
retailers exercise a form of structural power over production by virtue of their ability to control access to markets.

\section{GLOBAL PRODUCTION AND AFRICA}

A considerable literature has emerged in the last ten years examining the increasing importance of buyer driven global value chains in Africa. Production is increasingly carried out for buyer-driven value chains organized by TNCs based in core countries (Gibbon and Ponte 2005). Here again, an important degree of convergence between southern and tropical Africa is visible.

The increased prominence of these value chains has changed the ways in which production in Africa is organised. Small-scale producers in horticultural sectors have been unable to meet the standards for cost, quality, and flexibility required by retailers in Europe. The end result has often been a shift to production on large farms employing wage labour studies of Kenya's export horticulture sector (Dolan and Humphrey 2000, McCullough and Ota 2002, Gibbon 2003a, Jensen 2008), and South Africa's citrus sector (Mather and Greenberg 2003) reflect this pattern. In the case of traditional export crops - cocoa, cotton and coffee - African participation in global value chains has increasingly been restricted to agricultural production, as intermediate forms of processing come under pressure from the quality and cost demands of global buyers (Gibbon and Ponte 2005: 145-160, Fold and Ponte 2008, Ponte 2002, Mosley and Gray 2008). Some new sectors have emerged as well. Clothing manufacturers moved first into South Africa and Mauritius and then on to lower-wage jurisdictions - especially Madagascar and Lesotho, but also increasingly Tanzania and Kenya seeking out low wages in response to growing cost pressures from lead firms in the garment industry (Gibbon and Ponte 2005: 138-140; Gibbon 2003b, 2003c).

These developments have been linked to the increasing informalization and casualization of work. In horticulture there are very few year-round permanent jobs either on farms or in processing facilities (Dolan 2004, Barrientos and Kritzinger 2004, Mather and Greenberg 2003). Labour in these sectors is overwhelmingly young, mostly female and dominated by workers seeking to supplement family income through temporary migration (Dolan 2004). The same is true of the garment industry in Lesotho and Madagascar (Gibbon 2003b, 2003c; Glick and Roubaud 2006) and mining in southern Africa, although in the latter case employment is still male-dominated (Niemann 2006). Casualization and migration have also contributed to the expansion of the informal economy and its increasing entwinement with the formal sector.

Many of these trends have been compounded by investments from China and other emerging markets. Chinese firms in particular have tended to prefer to import Chinese workers rather than hire local, especially in managerial positions. Chinese operations in Zambia's copper sector, both in mining itself and in retail and other services around the mines, have come under particularly harsh criticism on this point (Gadzala 2010, Lee 2009). Some Chinese and other East Asian firms have adopted similar hiring practices in the garment industry (Wong 2006, Brooks 2010, Lee 2009, Gibbon and Ponte 2005: 139). The rise of Chinese 
involvement in Africa is most notable here in its contribution to wider processes of informalization and casualization of work. ${ }^{2}$

Harrod's (1987) concept of 'unprotected work' is useful in understanding these changes (see Davies and Ryner 2006). Unprotected work is in precarious, informal, or marginal types of economic activity, directly or indirectly subject to the decisions of actors with structural power in which workers have no say. Of course, unprotected work has been prevalent in Africa for the entire period in question, and indeed we should not attribute the increase in informal and casual work entirely to globalization - retrenchment in the public sector has also contributed (Wood and Brewster 2007). The globalization of production is nonetheless significant in two ways. First, the relative prevalence of particular forms of unprotected work has shifted as Africans have both been pushed out of subsistence-smallholder agriculture into (often casualized) wage work and out of formal sector jobs into the informal sector and casual wage work. Second, these new patterns of unprotected work are more deeply entrenched as Africans are increasingly incorporated into hierarchically organized transnational relations of production subject to the structural power of distant core actors. While major TNCs are rarely directly involved in Sub-Saharan Africa, their influence over the structure of production - that is, over the range of possible configurations of economic organization - is increasingly important.

For states in Africa long hampered by limited institutional, financial, and human resources, these shifts in the social relations of production present considerable political problems. Civil society within and outside Africa, especially the increasingly independent trade unions, remains capable of mobilizing. At times this has taken the form of nationalist responses to foreign involvement - exemplified by the anti-Chinese rhetoric of Michael Sata's campaigns in the 2006 and 2011 elections in Zambia (see Larmer and Fraser 2007). More important, though, is the broader loss of control over the trade union movement in the context of profound labour market restructuring. Conventional forms of labour regulation are less applicable and less effective than previously, yet labour politics are also more pressing.

\section{THE ILO, THE INTERNATIONAL LABOUR MOVEMENT, AND GLOBAL PRODUCTION}

Of course, many of these trends are not confined to Africa. Guy Standing (1999), among others, has noted the global erosion of secure, stable, and protected work in favour of more flexible modes of labour organization. A number of authors have noted the challenges this has posed for the ILO (e.g. Cooney 1999, Helfer 2006, Maupain 2009, Hughes 2005), and for existing configurations of international labour more generally (O’Brien 2000, Myconos 2005). The ILO's organization and goals were tied to a fairly rigid set of conventions of questionable enforceability and based in a mode of industrial organization under threat even in the narrow segment of the globe to which it had ever applied.

Efforts to establish new modes of labour standards in response to the pressures of global production date from the late 1980s. The ILO was more or less sidelined, as the international labour movement focused on organizations like the World Trade Organization (WTO) and International Monetary Fund (IMF) with the ability to sanction violators (Myconos 2005: 
145). The issue came to a head in 1996 at the WTO's Singapore Ministerial where the US and European delegations, under pressure from the International Confederation of Free Trade Unions, pushed for a resolution incorporating labour standards into the WTO's rules (see O'Brien et al. 2000). The final resolution in Singapore did reaffirm the ILO's status as the appropriate institution to manage international labour standards. However, the position of the ILO at the time was such that the decision of the Singapore Ministerial might be attributed primarily to a desire among states and business actors to avoid enforceable labour standards.

The ILO was not unique in struggling to situate itself with respect to new patterns of social relations of production. Engaging with transnational business remains a challenge for the United Nations system as a whole (Ruggie 2004, Pauly 2008). The issue is, however, particularly pressing for the ILO, whose purpose and fundamental organizing principles have been called into question.

\section{Africa and the New ILO}

The ILO's response to these challenges has also been one of the most sweeping. It strongly de-emphasized its old framework of conventions. The 1998 Declaration on Fundamental Principles and Rights at Work reoriented the institution's focus towards four 'core' conventions: the elimination of child labour, the elimination of forced labour, guarantees of freedom of association, and anti-discrimination policies. Shortly thereafter, in 1999 the ILO announced a new 'Decent Work' agenda with four main objectives: promoting employment, promoting rights at work, promoting social protections, and promoting 'social dialogue' (ILO 1999). In short, 'Decent Work' was a shift away from rigid conventions towards more a more flexible language. A less formally stated but no less significant change has been the increased emphasis given to the ILO's operations in the developing world, especially Africa.

Three significant new patterns of ILO activity in Africa are visible. First, the ILO has taken on an active role in policy-making and resource allocation. Second, it has moved towards serious engagement with TNCs and corporate social responsibility (CSR) programs. These two developments are considered in more detail below. A third trend has been a move beyond labour standards to deal more substantively with issues of social policy and development. For instance, the ILO has been involved in pension reform debates in Africa - often serving as a counterweight to IMF and World Bank demands for liberalization (see Kpessa and Beland 2012). It has also established a 'Cooperative Facility for Africa' (CoopAfrica) promoting purchasing cooperatives for the urban poor in Eastern and Southern Africa. For the sake of space, the paper only deals in detail with the first two developments, which are directly relevant to labour standards.

\section{Decent Work Country Programs - From Standard Setting to Active Policy Making}

'Decent Work Country Programs' (DWCPs) are broad national strategies for implementing the Decent Work agenda. They are established through consultations between 
states, business associations and civil society with the ILO, intended to allow for policy measures to be tailored to the exigencies of particular settings. They are intended to formulate policy instruments for achieving the broad goals of the Decent Work agenda, as well as to identify areas where the ILO's technical and financial assistance are needed (ILO 2008a, Ghai 2006).

Significantly, Africa is disproportionately represented among countries who have adopted or are in the process of formulating DWCPs. At the time of writing, 20 of 61 currently active DWCPs, as well as 25 of 49 in the drafting stage, had been established in Africa (ILO 2011a). The rest of this section considers the contents and implementation of African DWCPs, and the ways in which African states and civil society have engaged with these programs.

\section{THE ANATOMY OF THE DWCPS}

The DWCPs all identify priority areas for labour and employment policy. At the time of writing there were 20 DWCPs publicly available; Table 1 provides a breakdown of the priority areas identified in these programs. ${ }^{3}$ The first notable aspect of the programs is the uneven application of the four pillars of the Decent Work agenda. All of the DWCPs currently available highlight employment promotion, often focusing on creating opportunities in the formal sector for young workers. Further, in some cases - for example Madagascar (ILO 2010a) and Sierra Leone (ILO 2010b) - 'social protection' and 'social dialogue' are framed as issues of 'productivity' or 'competitiveness'. About half highlight strengthening social dialogue and expanding social protection. Only five highlight improving labour standards or rights at work, with another three (Tanzania, Uganda, and Zambia) specifically focusing on eliminating child labour.

The programmes also specify arrangements for implementing the DWCPs. National committees for implementing the DWCP are called for in most of the programs. These committees are, in theory, administered by national 'social partners' under the supervision of the ILO's regional offices. The ILO is also called on to play a role in mobilizing financial aid and technical expertise. Some programs include budgets, for example Cote D'Ivoire (ILO, 2008b) and Botswana (ILO, 2011c). The DWCP for Ethiopia even specifies particular foreign governments' agencies from which the ILO is to pursue funding for the Ethiopian programme (ILO, 2009a). The ILO is positioned as a 'gatekeeper' of sorts for development aid, its approval is needed for states to access funds from donors.

Admittedly this 'gatekeeper' role raises the question of the autonomy of the ILO from donors in setting policy priorities. Nonetheless, the variability in the application of core conventions in Decent Work programs suggests that if there is pressure on the ILO from these sources it is minimal. 'Decent Work' ought to be read mainly as a package of discursive and material resources made available to, and negotiated with, African states rather than a set of rules in and of itself. Clearly the rules are variable. 


\begin{tabular}{|c|c|}
\hline Priority Area & Countries \\
\hline Employment Promotion & $20-$ All \\
\hline $\begin{array}{l}\text { Strengthening Social } \\
\text { Dialogue/Tripartism }\end{array}$ & $\begin{array}{l}12 \text { - Benin, Botswana; Comoros; Kenya; Lesotho; Madagascar; } \\
\text { Mauritius; Namibia; Seychelles; Sierra Leone; South Africa; } \\
\text { Zimbabwe }\end{array}$ \\
\hline $\begin{array}{l}\text { Strengthening/Expanding Social } \\
\text { Protection }\end{array}$ & $\begin{array}{l}11 \text { - Benin, Botswana; Comoros; Ethiopia; Kenya; Lesotho; } \\
\text { Malawi; Namibia; Sierra Leone; South Africa; Togo }\end{array}$ \\
\hline HIV/AIDS in the Workplace & 6 - Lesotho; Namibia; Tanzania; Uganda; Zambia; Zimbabwe \\
\hline $\begin{array}{l}\text { Improved Labour } \\
\text { Standards/Administration or Rights at } \\
\text { Work }\end{array}$ & 5 - Botswana; Comoros; Ethiopia; Seychelles; South Africa \\
\hline Elimination of Child Labour & 3 - Tanzania; Uganda; Zambia \\
\hline $\begin{array}{l}\text { Elimination of Discrimination/Gender } \\
\text { Equity }\end{array}$ & 2 - Mauritius; Zimbabwe \\
\hline Other & $\begin{array}{l}2 \text { - Lesotho (special focus on garment/textile sector, improving } \\
\text { competitiveness of SMEs); Malawi (improving service delivery) }\end{array}$ \\
\hline
\end{tabular}

Source: author

\section{THE DWCPS AS RESOURCES FOR POLITICAL ACTION}

The important question to consider here is what role the DWCPs have played in the engagements of states and organised labour with the challenges posed by global production. One way to go about answering this question is to look at the extent to which states' commitments under the DWCPs have been implemented. The problem, however, is that most of these programmes are quite new and very little material on their implementation is available. This is compounded by two further problems. First, the ILO tends to focus narrowly on changes to legislation in evaluating the progress of its programmes (see ILO 2006, 2007a, 2008c, 2009b). Second, data collection on labour and workforce issues in Africa is often quite limited. Nonetheless, a few early indicators of the practical applications of the DWCPs are telling.

One source of information comes from ILO-commissioned independent reviews of recently completed programmes in Tanzania and Zambia. The review of Zambia's DWCP found mixed results. On the one hand, the ILO seems to have played a significant role in mobilizing resources and building capacity for trade unions, business organisations, and the Ministry of Labour and Social Services (Kumar-Range and Henry 2008: 19-23). The review was critical, though, of the applicability of the DWCP's priorities to the upwards of 80 percent of the working population engaged in the informal sector. It also complains of the vagueness of the programme's priorities and strategies (Kumar-Range and Henry 2008: 25-28). 
Many of the same problems were evident in Tanzania (Dagsteer and Guzman 2010). The problems posed by the lack of measurable goals are again raised in the report. The authors also note that the DWCP in Tanzania seems to have been formulated by the ILO without much input from the Ministry of Labour or civil society actors. While the DWCP did result in some important capacity building for Ministry of Labour, there is no mention in the report of similar efforts to develop the capacities of civil society groups. Indeed, the report hints that the ILO's activities in Tanzania overlapped or conflicted with those of non-governmental organisations and civil society (Dagsteer and Guzman 2010: 28). The relative neglect of the informal sector is also mentioned as a problem. The ambiguity of the DWCP priorities, then, seems to have inhibited their implementation and their effectiveness in actually raising labour standards in practice.

However, to stop here would miss the significance of the move to the DWCPs from more rigid standards and conventions in practice. The ambiguity of the DWCPs enhances their usefulness to some actors as political resources. Three examples are illustrative here. The ILO's technical cooperation functions, boosted by the Decent Work Agenda, have facilitated trade union input into the Organization pour l'Harmonization en Afrique du Droit des Affaires (OHADA) code of labour rights. OHADA is a regional institution seeking to harmonize business regulations across Francophone Africa. A common code for labour rights has been planed since 1992 but little progress has been made until recently. The ILO's emphasis on 'social dialogue' under Decent Work has both helped to push the initiative forward - albeit not to the point of the adoption of a common code at the time of writing - and has enabled labour input into its contents (Blackett 2011).

Similarly, Zambian domestic workers, again facilitated by resources made available by the country's DWCP, have taken to participating in ILO and International Trade Union Confederation campaigns for domestic workers' rights. They have had some notable successes. Most important has been an increase in the minimum wage for domestic workers (Times of Zambia 2012).

Finally, the Southern African Trade Union Coordination Council (SATUCC) (a regional trade union confederation within the Southern African Development Community) has recently adopted the idea of 'Decent Work' into its policy advocacy. In 2005 the SATUCC issued an outline of an 'Alternative Development' framework for Southern Africa in which Decent Work is not mentioned, and the ILO in general is referenced once (Kanyenze 2005). By 2010 'Decent Work' was a core focal point of the organization's advocacy. The SATUCC published a policy paper highlighting the need to focus on poverty reduction in order to accomplish the Decent Work agenda (Makanza 2010). Much of the substantive content of the two documents is similar, but the 2010 paper advertises itself as advancing 'Decent Work'.

The important point about all three of these cases is that trade unions have found it useful to engage with the ILO's resources and to try to frame their claims in ways that are compatible with the ILO's initiatives. There are, however, certain patterns of exclusion that might also come with the availability of these resources. They are available only to more established forms of labour organization. The increasing proportion of the population engaged in unprotected forms of work has little access to the set of resources that come with DWCPs, 
indeed the programmes themselves are notable for their neglect of the informal sector. Marginal workers will only benefit from the ILO's programmes only to the extent that more established workers concern themselves with them.

Further, the resources provided through Decent Work need not necessarily be employed in the interests of workers at all. The government of Zimbabwe moved to abolish some of the National Employment Councils (NECs) set up to supervise the implementation of the country's DWCP in early 2012. It claimed that employers and unions in the NECs had been colluding to exploit the DWCPs for private gain, holding deliberately over-long meetings in order to be able to claim higher meeting allowances and siphoning off resources. A spokesperson for the government claimed such actions undermined the objectives of Decent Work (The Herald 2012). Two possible explanations suggest themselves. It is possible that the DWCP in Zimbabwe is in fact being exploited for personal gain by unions and business associations. Alternatively, it is possible the Zimbabwean government has fabricated or exaggerated a concern about corruption in order to avoid implementing the policies in its DWCP without actually having to disavow 'Decent Work'. In either event, the most important implication is that the DWCPs and the language of 'Decent Work' are relatively open for a variety of uses (and abuses), but nonetheless presents an appealing political and ideological language for states and labour.

The applications of DWCPs, then, are indicative both of the underlying reasons for the deeper engagement between the ILO and African states and the limits on their effectiveness. They represent a useful political means for the ILO and African states to legitimise their authority over labour relations in spite of the considerable governance challenges posed by the global reorganization of production relations. The idea of 'Decent Work' and the resources provided by the ILO provide an appealing, yet ultimately unthreatening, avenue for trade unions and states to pursue the advancement of their own political preferences. They risk reinforcing existing patterns of exclusion and dominance in making resources available only to established actors. In short, the DWCPs have facilitated modes of action and ordering that might not necessarily work to the benefit of unprotected workers.

\section{Better Work Lesotho - Engaging With Private Authority}

While the DWCPs have been the primary means of engaging with the ILO for most African states, the ILO has also made serious efforts to engage with private authority. In the simplest sense the ILO's core conventions are used as the basis for labour standards in most voluntary regulatory programs. The ILO, however, rarely has any active role in shaping these programs outside some meetings or informal consultations (see ILO 2007b).

In recent years the ILO has taken on a much more active role in this respect through its 'Better Work Initiative'. Better Work is joint-operated by the ILO and the International Finance Corporation (IFC - the private lending arm of the World Bank). Where DWCPs focus on national level policies, Better Work is aimed ensuring compliance with labour standards at the factory level in sectors producing for global buyers. Private actors, including 
major TNCs, are thus much more prominently involved both in the formulation and implementation of Better Work.

Africa is less central to the Better Work Initiative than it is to Decent Work. At present the only African Better Work Programme is in Lesotho. Nonetheless some important patterns are visible in Better Work Lesotho. Better Work builds on the previous extension of private authority over labour relations in the garment industry in Lesotho. The ILO provides a source of financial resources, technical expertise, and above all legitimacy for business and trade union actors who have been participating in CSR programs in Lesotho since the 1990s. It is a set of resources that have facilitated processes of political ordering. In this case, however, these processes had been ongoing to a much greater extent prior to the ILO's involvement.

Already in 1994, the Lesotho Clothing and Allied Workers Union (LECAWU) had established links with the US Department of Labour (DoL), providing evidence used to write a report on child labour. LECAWU later participated in Northern civil society campaigns against sweatshop conditions in the garment industry between 1998 and 2002 (Gibbon 2003c). LECAWU's activities, however, have not necessarily been unambiguously positive. Gibbs (2005) argues that the union's international activities have mainly been used to gain access to material and political resources used to reinforce the sharply gendered hierarchy within the union, with the male union leadership doing little of actual benefit to the largely female workforce in garment factories. LECAWU has long sought international connections, but not necessarily in the best interests of its members.

Nonetheless, LECAWU's activism seems to have had some impacts on global buyers and suppliers. Buyers and suppliers linked to Lesotho's garment sector have seized on CSR programs as a way of raising the value of the clothes produced in the country. In 2008 the country's garment manufacturers unanimously adopted a sector-wide code of conduct in an effort to establish a market niche as a source of 'ethical' garments (Seidman 2009). In short, engagements between organized labour, garment manufacturers, foreign country governments, and global civil society had been ongoing for roughly fifteen years before the implementation of Better Work.

Better Work Lesotho formalizes and legitimizes these relationships. The United States DoL is the primary financial supporter of the program in Lesotho, but appears to have limited input into the actual implementation of the program (Better Work 2010). Of course, the fact that Lesotho is the focus of the program rather than, for instance, the comparable garment industry in Madagascar is probably in part explicable by the links between LECAWU and the DoL. However, most of the active work designing the program seems to have been carried out by the ILO and IFC, global garment buyers, local suppliers, and LECAWU. As a rough indication of the autonomy of Better Work from direct influence by the DoL, we might note the relatively low priority assigned to the elimination of child labour - increasingly central to the DoL's international activities (see DoL 2012) - in Better Work Lesotho.

The primary focus of Better Work Lesotho is on training and technical assistance for labour inspectors. It is intended to enhance the capacity of buyers and suppliers to enforce labour standards at the factory level (Better Work 2010, Better Work 2011). Better labour inspection is unquestionably needed in Lesotho; compliance with labour standards in Lesotho's 
garment factories has been a major problem (Pike and Godfrey 2011). In this sense to the extent that Better Work does contribute to improving the enforcement of labour standards it will make a positive contribution to work in Lesotho.

There are, however, some potential problems with the program. First, as Seidman (2009) suggests, tying the competitiveness of Lesotho's garment industry - and by extension the continued availability of jobs in the sector - to an image of 'ethical' production might in fact provide a disincentive for workers to raise complaints against employers in the sector. Undermining the 'ethical' image of Lesotho's garment sector by reporting violations is likely to be more costly for workers than suppliers. Further, Better Work legitimizes existing patterns ordering and action to the benefit of the narrow range of actors already participating in the private and transnational regulatory arrangements established in Lesotho since the 1990s.

Better Work is more oriented towards private authority than the DWCPs, but its basic function is similar. It represents an effort at responding to the political challenges and conflicts emerging from the globalization of production. The ILO's participation in this case is similarly valuable to the actors involved as a source of technical and financial resources and political legitimacy. Many of the same basic problems are also evident, it is not clear that the kinds of political-economic ordering taking place under Better Work Lesotho are necessarily of benefit to unprotected workers.

\section{Conclusion - Agency, Action, and Ordering in Global Politics}

The ILO's activities in Africa, then, have been fundamentally transformed in the last ten to fifteen years. We ought to understand these changes as efforts at establishing new forms of political economic order in response to the challenges raised by historical transformations in the social relations of production. The importance of changing patterns of production in shaping the ILO's role in Africa is underlined by the historical trajectory outlined here. It is significant that it is only in the last decade, with both the ILO and African actors facing complementary problems stemming from the globalization of production, that the ILO has played a significant role in Africa. It is the political responses of African states, trade unions, and the ILO to the reorganization of production - their efforts to maintain their political positions in the face of the erosion of the forms of social relations of production that had underpinned them - that have shaped the ILO's role in Africa in the last fifteen years.

By way of conclusion, it is worth considering the significance of the ILO in SubSaharan Africa in relation to the broader transformation of the ILO's role in the global political economy since the late 1990s. The application of the programmes in Africa suggests that the ILO's self-reinvention has been significant in the kinds of discursive spaces and material resources it has made available for actors in a particular context. This has important implications for the ways in which we ought to go about answering the explanatory and evaluative questions posed above. How the ILO frames itself or what rules it sets do not matter so much as how those rules are put into practice. The unevenness of the ways in which ILO programmes have been implemented and used even within Africa underscores this point. 
This argument might be further explored with more explicit comparison between the ILO's activities in different developing contexts and in other policy areas. Rodriguez-Pinero's (2005) study of the ILO's Indigenous Rights conventions points to some dynamics similar to those highlighted here. The pre-war colonial order shaped the ways in which the organization conceived of indigeneity. On the other, the ways in which states and indigenous groups have engaged with and sought to reform the ILO's conventions on indigenous rights have had profound impacts. The comparison to East Asia may also be informative. The ILO has had limited success in encouraging changes to labour laws outside the implementation of an ambitious factory monitoring program in Cambodia (see Caraway 2010, Kolben 2004). The Sialkot Child Labour Elimination Project in the Pakistani soccer ball industry, in which the ILO has played a key role, is similar in its focus on a politically appealing, but limited area of labour rights at the expense of dealing with wider structural issues (see Boje and Khan 2009). A wider comparative discussion is beyond the scope of this paper, but it is a potentially fruitful direction for research.

The most that can be said at present is that Decent Work and Better Work are open for a variety of forms of action, and that the actions of subaltern actors are not necessarily progressive. As many workers and governments in Africa have used the new rules in ways that legitimize and reinforce existing structures of power and accumulation as have used them to advance the interests of unprotected workers. More fundamentally, the resources made available by Decent Work and Better Work are only available to established actors - recognized trade unions and states. In this sense the ILO's programmes reinforce existing patterns of power and exclusion. In approaching the problem this way, we can start to get at the ways in which the ILO has helped to reinforce existing patterns of production without losing sight of the ways in which it might help to transform them if used in certain ways. We ought to approach the ILO's activities as acts of ordering, not as a finished order.

The chief importance of this rather cursory overview of the ILO's activities in Africa, then, is to suggest that global governance is an iterative, historically contingent, and dialectical process. It is best thought of not as a process of making and enforcing rules, but as a set of frameworks and resources that can be applied to differing political projects. The ILO's new agenda since the late 1990s opened up a new set of political, discursive, and material resources for African states and trade unions faced with the erosion of the forms of social relations of production on which their activities used to rest. The ILO has facilitated thus far partial and incomplete efforts at reordering in Africa. The significance of the role of the ILO in SubSaharan Africa accordingly lies not so much in the fact that the institution has found a new niche in the context of globalizing relations of production, but rather in the ways in which it has enabled some African workers and states to try to meet the challenges posed for them by those transformations while excluding others. 


\section{ACKNOWLEDGEMENTS}

An earlier version of this article was submitted as a Major Research Paper as part of an M.A. in International Relations in the Department of Political Science at McMaster University. I am grateful to Robert O'Brien for guidance and feedback in preparing that version. I would also like to thank two anonymous reviewers from this journal for helpful comments. This research was supported by the Social Sciences and Humanities Research Council of Canada's Joseph Armand Bombardier Canada Graduate Scholarship program. The standard disclaimer applies.

\section{NOTES}

1. I am grateful to an anonymous reviewer for raising this point.

2. There is a wider debate here about the role of Chinese investments in Africa (see Carmody, Hampwaye and Sakala 2012, Davies 2011, Ayers 2012). It should suffice to note that my own position is closest to Ayers' (2012) assertion that Chinese involvement is part of wider processes of capitalist globalization.

3. This information here and in Table 1 is based on my own examination of the DWCPs available at the time of writing, which are available at www.ilo.org/public/english/bureau/ program/dwcp/countries/index.htm. It would be cumbersome to cite all 20, I have only included those country programmes referenced in the text in the reference list. The priorities in the table are categorized according to the way in which they are formulated in the DWCP document. Some of the categories may overlap. The elimination of child labour, for instance, is often treated as a fundamental right at work. They are nonetheless presented in this way as a rough indication of the priority assigned to different policy areas. Because most of the DWCPs in West Africa were expired and new plans were being drafted at the time of writing, the information presented here is skewed towards Southern and Eastern Africa. However, there does not seem to be anything exceptional about the West African DWCPs included here.

\section{REFERENCES}

Ayers, A. (2012) 'Beyond Myths, Lies and Stereotypes: The Political Economy of a "New Scramble for Africa". New Political Economy, iFirst, DOI: $10.1080 / 13563467.2012 .678821$ 
Barnett, M. and Finnemore, M. (2004) Rules for the World: International Organizations in Global Politics. Ithaca: Cornell University Press.

Barrientos, S. and Kritzinger, A. (2004) 'Squaring the Circle: Global Production and the Informalization of Work in South African Fruit Exports', Journal of International Development 16 (1): 81-92.

Bayart, J-F. (2009) The State in Africa: The Politics of the Belly, $2^{\text {nd }}$ English ed. New York: Polity.

Berg, E. J. (1966) 'Major Issues of Wage Policy in Africa'. In A.M. Ross (ed) Industrial Relations and Economic Development (pp. 185-208). London: Macmillan.

Better Work (2010) Better Work Lesotho Project Summary. Available at: http://www.betterwork.org/EN/resources/Pages/home.aspx [Accessed 10 October 2012].

Better Work (2011) Better Work Programme Update, May-June 2011. Available at: http://www.betterwork.org/EN/resources/Pages/home.aspx [Accessed 10 October 2012].

Blackett, A. (2011) 'Beyond Standard Setting: A Study of ILO Technical Cooperation on Regional Labor Law Reform in West and Central Africa', Comparative Labour Law \& Policy Journal 32(2): 443-492.

Blanpain, R. and Engels, C. (2001) The ILO and the Social Challenges of the 21t Century: The Geneva Lectures. The Hague: Kluwer Law International.

Boje, D.M. and Khan, F.R. (2009) 'Story-branding by Empire Entrepreneurs: Nike, Child Labour, and Pakistan's Soccer Ball Industry'. Journal of Small Business and Entrepreneurship 22(1): 9-24.

Brooks, A. (2010) 'Spinning and Weaving Discontent: Labour Relations and the Production of Meaning at Zambia-China Mulungushi Textiles', Journal of Southern African Studies 36 (1): 114-132.

Caraway, T.L. (2006) 'Freedom of Association: Battering Ram or Trojan Horse?', Review of International Political Economy 13(2): 210-232.

Caraway, T.L. (2010) 'Labour Standards and Labour Market Flexibility in East Asia', Studies in Comparative International Development 45(2): 225-249.

Carmody, P., Hampwaye, G., and Sakala, E. (2011) 'Globalization and the Rise of the State? Chinese Geogovernance in Zambia’. New Political Economy 17(2): 209-229. 
Cooney, S. (1999) 'Testing Times for the ILO: Institutional Reform for the New International Political Economy', Comparative Labour Law \& Policy Journal 20(3): 365-399.

Cox, R. (1977) 'Labour and Hegemony', International Organization 31(3): 385-424.

Cox, R. (1980) 'Labour and Hegemony: A Reply', International Organization 34(1): 159-176.

Cox, R. (1987) Production, Power and World Order: Social Forces in the Making of History. New York: Columbia University Press.

Dagsteer, A. and Guzman, F. (2010) Independent Evaluation of the ILO's Country Program for the United Republic of Tanzania: 2004-2010. Geneva: International Labour Organization.

Davies, J.E. 2011. 'Washington's Growth and Opportunity Act or Beijing's "Overarching Brilliance”: Will African Governments Choose Neither?'. Third World Quarterly 32(6): 1147-1163.

Davies, M. and Ryner M., eds. (2006) Poverty and the Production of World Politics: Unprotected Workers in the Global Political Economy. New York: Palgrave Macmillan.

Dolan, C. S. (2004) 'On Farm and Packhouse: Employment at the Bottom of a Global Value Chain', Rural Sociology 69(1): 99-126.

Dolan, C. S. and Humphrey, J. (2000) 'Governance and Trade in Fresh Vegetables: The Impact of UK Supermarkets on the African Horticulture Industry', Journal of Development Studies 37(2): 147-176.

Fold, N. and Ponte, S. (2008) 'Are (Market) Stimulants Injurious to Quality? Liberalization, Quality Changes, and the Reputation of African Coffee and Cocoa Exports'. In N. Fold and M.N. Larsen (eds), Globalization and the Restructuring of African Commodity Flows (pp. 129-155). Uppsala: Nordiska Afrikainstitutet.

Gadzala, A. (2010) 'From Formal- to Informal-sector Employment: Examining the Chinese Presence in Zambia', Review of African Political Economy 37(1): 41-59.

Gereffi, G. (1994) 'The Organization of Buyer-driven Global Commodity Chains: How U.S. Retailers Shape Overseas Production Networks'. In G. Gereffi and M. Korzeniewicz (eds), Commodity Chains and Global Capitalism (pp. 95-122). Westport, CT: Greenwood Press. 
Gereffi, G. and Korzeniewicz, M., eds. (1994) Commodity Chains and Global Capitalism. Westport, CT: Greenwood Press.

Gereffi, G., Humphrey, J. and Sturgeon, T. (2005) 'The Governance of Global Value Chains', Review of International Political Economy 12(1):78-104.

Ghai, D. (2006) Decent Work: Objectives and Strategies. Geneva: International Labour Office.

Gibbon, P. (2003a) 'Value-chain Governance, Public regulation and Entry Barriers in the Global Fresh Fruit and Vegetable Value Chain Into the EU', Development Policy Review 21(5-6): 615-625.

Gibbon, P. (2003b) 'The Africa Growth and Opportunity Act and the Global Commodity Chain for Clothing', World Development 31(11): 1809-1827.

Gibbon, P. (2003c) 'AGOA, Lesotho's "Clothing Miracle" and the Politics of Sweatshops'. Review of African Political Economy 30(96): 315-320.

Gibbon, P. and Ponte, S. (2005) Trading Down: Africa, Value Chains and the Global Economy. Philadelphia: Temple University Press.

Gibbs, T. (2005) 'Union Boys in Caps Leading Factory Girls Astray? The Politics of Labour Reform in Lesotho's Feminized Garment Industry', Journal of Southern African Studies 31(1): 95-115.

Gill, S. and Law, D. (1989) 'Global Hegemony and the Structural Power of Capital', International Studies Quarterly 33(4): 475-499.

Glick, P. and Roubaud, F. (2006) 'Export Processing Zone Expansion in Madagascar: What are the Labour Market and Gender Impacts', Journal of African Economies 15(4): 722756.

Harrod, J. (1987) Power, Production, and the Unprotected Worker. New York: Columbia University Press.

Helfer, L.R. (2006) 'Understanding Change in International Institutions: Globalization and Innovation in the ILO', Vanderbilt Law Review 59(3): 649-726.

Henderson, J., Dicken, P., Hess, M., Coe, N. and Wai-Chung Yeung, H. (2002) 'Global Production Networks and the Analysis of Global Production', Review of International Political Economy 9(3): 436-464. 
The Herald (2012) 'Ministry Seeks to Improve Labour Governance, Curb Abuse', The Herald, 6 Feb.

Hughes, S. (2005) 'The International Labour Organization', New Political Economy 10(3): 413-425.

ILO (International Labour Organization) (1999) Report of the Director General: Decent Work. Geneva: International Labour Office.

ILO (2006) Progress in Implementation of Decent Work Programmes. Geneva: Committee on Technical Cooperation, Governing Body, International Labour Office.

ILO (2007a) Implementation of Decent Work Country Programmes. Geneva: Committee on Technical Cooperation, Governing Body, International Labour Office.

ILO (2007b) Updates on Corporate Social Responsibility (CSR)-related Activities. Geneva: Subcommittee on Multinational Enterprises, Governing Body, International Labour Office.

ILO (2008a) ILO Decent Work Country Programmes: A Guidebook. Geneva: International Labour Office.

ILO (2008b) Cote D'Ivoire - Code Pays Pour the Travail Décent: 2008-2013. Abdijan, Cote D'Ivoire: International Labour Organization.

ILO (2008c) Implementation of Decent Work Country Programmes. Geneva: Committee on Technical Cooperation, Governing Body, International Labour Office.

ILO (2009a) Decent Work Country Programme Ethiopia (2009-2012). Addis Ababa: International Labour Organization.

ILO (2009b) Implementation of Decent Work Country Programmes. Geneva: Committee on Technical Cooperation, Governing Body, International Labour Office.

ILO (2010a) Programme Pays Pour le Travail Decent 2010-2013: Madagascar. Antanannarivo, Madagascar: International Labour Office, Republic of Madagascar.

ILO (2010b) Sierra Leone Decent Work Country Program: 2010-2012. Freetown, Sierra Leone: International Labour Organization.

ILO (2011a) 'Status of Decent Work Country Program Development by Region'. Available at: http://www.ilo.org/public/english/bureau/program/dwcp/countries/index.htm. [Accessed 
2 January 2012].

ILO (2011b) Decent Work Programme for Botswana 2011-2015. Gaborone, Botswana: International Labour Office.

Jeffries, R. (1978) Class, Power and Ideology in Ghana: The Railwaymen of Sekondi. London: Cambridge University Press.

Jensen, M.F. (2008) 'Changing Food Safety Requirements and the Export of Fresh Horticultural Products by Kenyan Smallholders', in N. Fold and M.N. Larsen (eds), Globalization and the Restructuring of African Commodity Flows (pp. 103-128). Uppsala, Sweden: Nordiska Afrikainstitutet.

Kalula, E. (1985) 'The Influence of International Labour Standards on Zambian Legislation', International Labour Review 124(5): 593-609.

Kanyenze, G. (2005) Alternative Socioeconomic Development Policies for the SADC: A Trade Union Perspective. Gaborone, Botswana: Southern African Trade Union Coordination Council.

Kaplinsky, R. (2010) 'The Role of Standards in Global Value Chains', The World Bank Poverty Reduction and Economic Management Network Working Paper 5396.

Kolben, K. (2004) 'Trade, Monitoring, and the ILO: Working to Improve Conditions in Cambodia's Garment Factories', Yale Human Rights and Development Law Journal 7: 79107.

Kpessa, M. and Beland, D. (2012) 'Transnational Actors and Politics of Pension Reform in Sub-Saharan Africa', Review of International Political Economy 19(2): 267-291.

Kraus, J. (2007) Trade Unions and the Coming of Democracy in Africa. New York: Palgrave Macmillan.

Kumar-Range, S. and Henry, C. (2007) Independent Evaluation of the ILO's Country Program for Zambia: 2001-2007. Geneva: International Labour Organization.

Larmer, M. and Fraser, A. (2007) 'Of Cabbages and King Cobras: Populist Politics and Zambia's 2006 Elections'. African Affairs 106(425): 611-637.

Lee, C.K. (2009) 'Raw Encounters: Chinese Managers, African Workers and the Politics of Casualization in Africa's Chinese Enclaves', The China Quarterly 199: 647-666. 
Lorenz, E.C. (2001) Defining Global Justice: The History of U.S. International Labour Standards Policy. Notre Dame, Indiana: University of Notre Dame Press.

Luke, D.F. (1984). Labour and Parastatal Politics in Sierra Leone: A Study of Working Class Ambivalence. Lanham, MD: University Press of America.

Makanza, T. (2010) Poverty Eradication and Sustainable Livelihoods: Making the Decent Work Agenda Work for the Region. Gaborone, Botswana: Southern Africa Trade Union Coordination Council.

Mather, C. and Greenberg, S. (2003) 'Market Liberalization in Post-Apartheid South Africa: The Restructuring of Citrus Exports after "Deregulation", Journal of Southern African Studies 29(2): 393-412.

Maupain, F. (2009) 'New Foundation or New Façade? The ILO and the 2008 Declaration on Social Justice and Fair Globalization', The European Journal of International Law 20(3): 823-852.

McCulloch, N and Ota, M. (2002) Export Horticulture and Poverty in Kenya. Brighton: Institute for Development Studies, University of Sussex.

Mosely, W.G. and Gray, L.C. (2008) Hanging by a Thread: Cotton, Globalization, and Poverty in Africa. Athens, Ohio: Ohio University Press.

Murphy, C.N. (1983) 'What the Third World Wants: An Interpretation of the Meaning and Development of the New International Economic Order Ideology', International Studies Quarterly 27(1): 55-76.

Myconos, G. (2005) The Globalizations of Organized Labour: 1945-2005. New York: Palgrave Macmillan.

Niemann, M. (2006) 'Migration and Unprotected Work in Southern Africa: The Case of the Mining Sector'. In M. Davies and M. Ryner (eds), Poverty and the Production of World Politics: Unprotected Workers in the Global Political Economy (pp. 137-153). New York: Palgrave Macmillan.

O'Brien, R. (2000) 'Workers and World Order: The Tentative Transformation of the International Union Movement', Review of International Studies 26(4): 533-555.

O’Brien, R., Goetz, A-M., Scholte, J.A. and Williams, M. (2000) Contesting Global Governance: Multilateral Economic Institutions and Global Social Movements. Cambridge, UK: Cambridge University Press. 
Panford, K. (1994) African Labor Relations and Workers' Rights: Assessing the Role of the International Labor Organization. London: Greenwood Press.

Pauly, L.W. (2008), 'The United Nations, the Bretton Woods Institutions, and the Reconstruction of a Multilateral Order'. In L.W. Pauly and W.D. Coleman (eds), Global Ordering: Institutions and Autonomy in a Changing World (pp. 23-43). Toronto: UBC Press.

Pike, K. and Godfrey, S. (2011), 'Lesotho's Apparel Industry: What is the Role for Better Work?', paper presented at Workers, Businesses, And Government: Understanding Labour Compliance In Global Supply Chains, International Finance Corporation, Washington DC, 26-28 October 2011.

Ponte, S. (2002) 'Brewing a Bitter Cup? Deregulation, Quality and the Re-organization of the Coffee Marketing Chain in East Africa', Journal of Agrarian Change 2(2): 248-272.

Rodgers, G., Lee, E., Swepston, L. and Van Daele, J. (2009) The ILO and the Quest for Social Justice, 1919-2009. Geneva: International Labour Office.

Rodriguez-Pinero, L. (2005) Indigenous Peoples, Postcolonialism, and International Law: The ILO Regime (1919-1989). New York: Oxford University Press.

Ruggie, J.G. (1982) 'International Regimes, Transactions, and Change: Embedded Liberalism in the Postwar Economic Order', International Organization 36(2): 379-415.

Ruggie, J.G. (2004) 'Reconstituting the Global Public Domain: Issues, Actors, and Practices', European Journal of International Relations 10(4): 499-531.

Seidman, G.W. (2009) 'Labouring Under an Illusion? Lesotho's "Sweat-free" Label', Third World Quarterly 30(3): 581-598.

Shaw, T.M. (1979) 'Dependence to (Inter)dependence: Review of the Debate on the (New) International Economic Order', Alternatives 4(4): 557-578.

Standing, G. (1999) Global Labour Flexibility. London: MacMillan.

Standing, G. (2008) 'The ILO: An Agency for Globalization?', Development and Change 39(3): 355-384.

Standing, G. (2010) 'The International Labour Organization', New Political Economy 15(2): 307-318. 
Strange, S. (1988) States and Markets. London: Pinter Publishers Limited.

Strange, S. (1996) The Retreat of the State: The Diffusion of Power in the World Economy. Cambridge, UK: Cambridge University Press.

Taylor, I. (2003) 'The United Nations Conference on Trade and Development', New Political Economy 8(3): 409-418.

Tidjani, B. (1998), 'African Unions Under Structural Adjustment Programs' Relations Industrielles 53(2): 278-299.

The Times of Zambia (2012) 'Minimum Wage Law - Workers See Light at the End of Tunnel', Times of Zambia, 30 January.

UNCTAD (United Nations Conference on Trade and Development) (2010) World Investment Report 2010. New York: United Nations.

UNCTAD (n.d.) UNCTADstat. Available at: http://unctadstat.unctad.org/ReportFolders/reportFolders.aspx. [Accessed 12 October 2011].

Vosko, L.F. (2002) “"Decent Work”: The Shifting Role of the ILO and the Struggle for Global Justice', Global Social Policy 2(1): 19-46.

Wong, M. (2006) 'Chinese Workers in the Garment Industry in Africa: Implications of the Contract Labour Dispatch System on the International Labour Movement', Labour, Capital and Society 39(1): 68-111.

Wood, G. and Brewster C., eds. (2007) Industrial Relations in Africa. New York: Palgrave Macmillan.

\section{BIOGRAPHICAL NOTE}

NICK BERNARDS is PhD student and Canada Graduate Scholar in International Relations in the Department of Political Science at McMaster University. His doctoral research examines patterns of international labour regulation in sub-Saharan Africa in historical perspective.

[email: bernarna@mcmaster.ca] 